Article

\title{
Efficient spinel iron-cobalt oxide/nitrogen-doped ordered mesoporous carbon catalyst for rechargeable zinc-air batteries
}

\author{
He-lei Wei a, Ai-dong Tan a,*, Shu-zhi Hu a, Jin-hua Piao b, Zhi-yong Fu a,\# \\ a Key Laboratory on Fuel Cell Technology of Guangdong Province, School of Chemistry and Chemical Engineering, South China University of Technology, \\ Guangzhou 510641, Guangdong, China \\ b School of Food Science and Engineering, South China University of Technology, Guangzhou 510641, Guangdong, China
}

\section{A R T I C L E I N F}

\section{Article history:}

Received 25 November 2020

Accepted 22 December 2020

Available online 5 May 2021

\section{Keywords:}

Oxygen-related catalyst

Oxygen evolution reaction

Oxygen reduction reaction

Spinel oxide

Zinc-air battery

\begin{abstract}
A B S T R A C T
A robust oxygen-related electrocatalyst, composed of spinel iron-cobalt oxide and nitrogen-doped ordered mesoporous carbon (NOMC), was developed for rechargeable metal-air batteries. Electrochemical tests revealed that the optimal catalyst $\mathrm{Fe}_{0.5} \mathrm{Co} / \mathrm{NOMC}$ exhibits superior activity with a half-wave potential of $0.89 \mathrm{~V}$ ( $v s$. reversible hydrogen electrode) for the oxygen reduction reaction and an overpotential of $0.31 \mathrm{~V}$ at $10 \mathrm{~mA} \mathrm{~cm}^{-2}$ for the oxygen evolution reaction. For demonstration, the catalyst was used in the assembly of a rechargeable zinc-air battery, which exhibited an exceptionally high energy density of $820 \mathrm{Wh} \mathrm{kg}^{-1}$ at $100 \mathrm{~mA} \mathrm{~cm}^{-2}$, a high power density of $153 \mathrm{~mW} \mathrm{~cm}^{-2}$ at $1.0 \mathrm{~V}$, and superior cycling stability up to 432 cycles $(144 \mathrm{~h})$ under ambient air.
\end{abstract}

(C) 2021, Dalian Institute of Chemical Physics, Chinese Academy of Sciences. Published by Elsevier B.V. All rights reserved.

\section{Introduction}

Electrochemical energy technology, including metal-air batteries and fuel cells, has been intensively investigated to tackle energy and environmental challenges [1-3]. Zinc-air batteries have attracted attention owing to their high energy density (1086 Wh kg-1), low cost, and safety, making them candidates for mobile and transport power applications [4,5]. In these batteries, the oxygen reduction reaction (ORR) and oxygen evolution reaction (OER) occur at the positive electrode during the discharging and charging processes, respectively [6,7]. Commercial noble metal-based catalysts, such as $\mathrm{IrO}_{2}\left(\mathrm{RuO}_{2}\right)$ and $\mathrm{Pt} / \mathrm{C}$, exhibit good electrocatalytic activity for the OER and ORR $[8,9]$. However, poor stability, source scarcity, and high cost seriously hamper their widespread application in $\mathrm{Zn}$-air batteries $[10,11]$. To address this issue, it is highly desirable to explore non-noble metal ORR/OER catalysts with high activity and stability [12-14].

Heteroatom-doped carbon has been identified as a promising electrocatalyst for the ORR [15-17]. However, carbon has rarely been applied in OER catalysts. The reasons include its intrinsically low OER activity and the inevitable carbon corrosion or structural collapse at high potentials [18]. Alternatively, loading transition metal (e.g. Fe, $\mathrm{Co}, \mathrm{Ni}$ ) oxides onto the carbon skeleton seems plausible for rationally designing a bifunctional catalyst [19-21]. Wu et al. [22] deposited CoO-NiO-NiCo on nitrogen-doped multi-wall carbon nanotubes as a composite electrocatalyst, which showed superior performance with an onset potential of $0.97 \mathrm{~V}$ ( $v s$. RHE) for the ORR and a low overpotential of $0.27 \mathrm{~V}$ for the OER. Wang et al. [23] synthesized a

\footnotetext{
* Corresponding author. Tel: +86-20-87113584; E-mail: tanad@scut.edu.cn

\# Corresponding author. E-mail: zyfu@scut.edu.cn

The work was supported by the National Natural Science Foundation of China $(21903026,21975081,21975079)$, China Postdoctoral Science Foundation (2019M652877), and the Fundamental Research Funds for the Central Universities.

DOI: 10.1016/S1872-2067(20)63752-4 | http:// www.sciencedirect.com/journal/chinese-journal-of-catalysis | Chin. J. Catal., Vol. 42, No. 9, September 2021
} 
hollow $\mathrm{NC}-\mathrm{Co}_{3} \mathrm{O}_{4}$ catalyst by embedding hollow $\mathrm{Co}_{3} \mathrm{O}_{4}$ nanospheres in nitrogen-doped carbon nanowall arrays, which enables promising catalytic properties for both the ORR and OER. $\mathrm{Lu}$ et al. [24] reported that an atom-thin mesoporous $\mathrm{Co}_{3} \mathrm{O}_{4}$ layer, which is strongly coupled with $\mathrm{N}-\mathrm{rGO}$ nanosheets and displays high performance towards the ORR/OER. In the aforementioned studies, the composite catalysts were mostly prepared in multiple steps, and the metal oxide was introduced into the pre-formed carbon frame $[25,26]$. As such, the loosely bound transition metal may tend to aggregate, thus degrading its electrocatalytic activity.

In this work, a precursor containing a transition metal and carbon is introduced in one step into the template of mesoporous silica. In this way, the iron-cobalt oxide has inherently intimate contact with the nitrogen-doped ordered mesoporous carbon (NOMC). A series of spinel iron-cobalt oxide-decorated NOMCs $\left(\mathrm{Fe}_{x} \mathrm{Co} / \mathrm{NOMC}\right.$, where $x$ refers to the ratio of $\left.\mathrm{Fe}: \mathrm{Co}\right)$ were prepared and investigated. Physiochemical characterization revealed that $\mathrm{Fe}_{x} \mathrm{Co} / \mathrm{NOMC}$ features a typical structural texture of NOMC with a narrow pore size distribution and high specific surface area, and the spinel oxide nanoparticles are uniformly dispersed within the carbon frame. Electrochemical analysis revealed that $\mathrm{Fe}_{0.5} \mathrm{Co} / \mathrm{NOMC}$ exhibited the highest activity and stability toward the ORR and OER. The ORR half-wave potential was $0.89 \mathrm{~V}$ ( $v s$. RHE) and the OER potential at $10 \mathrm{~mA} \mathrm{~cm}^{-2}$ was $1.54 \mathrm{~V}$, which is much lower than that of the $\mathrm{Pt} / \mathrm{C}$ and $\mathrm{IrO}_{2}$ benchmark. A rechargeable Zn-air battery assembled with $\mathrm{Fe}_{0.5} \mathrm{Co} / \mathrm{NOMC}$ in the air electrode achieved a peak power density of $230 \mathrm{~mW} \mathrm{\textrm {cm } ^ { - 2 }}$.

\section{Experimental}

\subsection{Materials preparation}

\subsubsection{Synthesis of the silica templates (SBA-15)}

The synthesis process of SBA-15 is referenced to our previous work [25,27]. Typically, 4.0 g of Pluronic P123 was completely dissolved in $126.0 \mathrm{~mL}$ of deionized (DI) water, and 20.0 $\mathrm{mL}$ of concentrated $\mathrm{HCl}$ (37.0 wt\%). Then, $9.20 \mathrm{~mL}$ of TEOS was added into the above solution and stirred for $20 \mathrm{~h}$ in a water bath at $35{ }^{\circ} \mathrm{C}$. The above slurry was hydrothermally reacted at $100{ }^{\circ} \mathrm{C}$ for $24 \mathrm{~h}$. The suspended solid was filtered, washed with DI water and dried. Finally, the obtained powders were pyrolyzed in air at $550^{\circ} \mathrm{C}$ for $6 \mathrm{~h}$ to remove the organic template.

\subsubsection{Synthesis of $\mathrm{Fe}_{\mathrm{X}} \mathrm{Co} / \mathrm{NOMC}$, Fe/NOMC and Co/NOMC}

First, $0.60 \mathrm{~g}$ of 1,10-phenanthroline monohydrate (3.0 mmol, Phen), $0.097 \mathrm{~g}$ of iron(II) acetate $(0.50 \mathrm{mmol})$ and 0.249 $\mathrm{g}$ of the cobalt(II) acetate tetrahydrate $(1.0 \mathrm{mmol})$ were dissolved in a solution containing $20.0 \mathrm{~mL}$ ethanol and $20.0 \mathrm{~mL}$ DI water. Second, $0.50 \mathrm{~g}$ of silica template SBA-15 was dispersed in the above solution by ultrasonic stirring for $6 \mathrm{~h}$ at room temperature. Then, the solvent was evaporated at $100{ }^{\circ} \mathrm{C}$, and the obtained powders were calcined at $900{ }^{\circ} \mathrm{C}$ for $3 \mathrm{~h}$ under argon (99.999\%). Finally, the precursor materials were washed with $10.0 \mathrm{~mol} \mathrm{~L}-1 \mathrm{NaOH}$ solution at $120{ }^{\circ} \mathrm{C}$ for $24 \mathrm{~h}$ to remove SBA-15. The resultant material is designated as $\mathrm{Fe}_{x} \mathrm{Co} / \mathrm{NOMC}$, where $x$ refers to the molar ratio of Fe:Co. For $x=0.5,1$ and 2, the feeding molar ratios of Fe:Co:Phen are 0.5:1:3, 0.75:0.75:3 and 1:0.5:3, respectively.

For comparison, we also prepared monometallic materials, viz. Fe decorated NOMC (Fe/NOMC) and Co decorated NOMC (Co/NOMC). The synthesis was similar to that of $\mathrm{Fe}_{x} \mathrm{Co} / \mathrm{NOMC}$, except for the metal precursor used.

\subsubsection{Electrochemical characterization}

The electrochemical evaluation of ORR and OER was performed in a standard three-electrode system using CHI630e electrochemical workstation at room temperature, in which rotating disk electrode (Glassy carbon disk: $5.0 \mathrm{~mm}$ in diameter, RDE) as working electrode, saturated calomel electrode (SCE for the ORR) and $\mathrm{Hg} / \mathrm{HgO}$ electrode (for the OER) as reference electrode, gold gauze as counter electrode and $0.10 \mathrm{M}$ $\mathrm{KOH}$ (ORR) or 1.0 M KOH (OER) as electrolyte, respectively.

The thin-film electrode on the disk was prepared as follows. $10 \mathrm{mg}$ of powder were dispersed in $1.0 \mathrm{~mL}$ of Nafion/ethanol (0.84 wt\% Nafion) by sonication for $1 \mathrm{~h}$ to obtain a homogeneous dispersion solution. Then, the ink was dropped on the RDE with a loading of $10.0 \mu \mathrm{L}\left(0.5 \mathrm{mg} \mathrm{cm}^{-2}\right)$. For comparison, the electrocatalytic activity of the commercial 40 wt\% Pt/C (HiSPEC4000, Johnson Matthey) for the ORR and the commercial $\mathrm{IrO}_{2}$ (P40V030, Premetek Co.) for the OER was evaluated with a metal loading of 20.0 and $500.0 \mu \mathrm{g} \mathrm{cm}^{-2}$, respectively.

For the electrochemical test, the electrolyte solution was bubbled with either argon or oxygen for $1 \mathrm{~h}$. The cyclic voltammograms (CVs) were recorded at $30 \mathrm{mV} \mathrm{s}^{-1}$ between 0 and $1.05 \mathrm{~V}$ (vs. reversible hydrogen electrode, RHE) for 30 cycles. The linear sweep voltammograms (LSVs) were recorded by scanning the disk potential from 1.05 down to $0 \mathrm{~V}$ for the ORR and from 1.0 to $1.8 \mathrm{~V}$ for the OER, respectively, at a rate of $5 \mathrm{mV} \mathrm{s}^{-1}$ under $1600 \mathrm{rpm}$.

The RRDE test was performed to measure the electron transfer number $(n)$, as calculated by the following equation.

$$
n=4 \times \frac{I_{\text {disk }}}{\left(\frac{I_{\text {ring }}}{N}\right)+I_{\text {disk }}}
$$

where $I_{\text {disk }}$ is the disk current (A), $I_{\text {ring }}$ is the ring current (A), and $N(20.5 \%)$ is the current collection efficiency of Pt ring.

\subsubsection{Assembly of rechargeable zinc-air battery}

Catalyst ink was prepared by dispersing the catalyst and Nafion (5.0 wt\% in EtOH) with a weight ratio of 9:1 in water $(20.0 \mathrm{~mL})$ and EtOH $(20.0 \mathrm{~mL})$. Then, the catalyst ink was uniformly brushed onto the gas diffusion layer at $70{ }^{\circ} \mathrm{C}$. The catalyst loading was $1.0 \pm 0.1 \mathrm{mg} \mathrm{cm}^{-2}$ for $\mathrm{Fe} 0.5 \mathrm{Co} / \mathrm{NOMC}$ and $0.50 \pm$ $0.05 \mathrm{mg} \mathrm{cm}^{-2}$ for $\mathrm{Pt} / \mathrm{C}+\mathrm{IrO}_{2}$, respectively.

A home-made zinc-air battery was used to evaluate the polarization performance and cycling stability. A polished zinc plate $\left(2.0 \times 1.0 \mathrm{~cm}^{2}\right)$ and the air electrode were used as the negative and positive electrode, respectively. The area of the cathode exposed to the air was about $0.785 \mathrm{~cm}^{2}$. The electrolyte used in the zinc-air battery system was $6.0 \mathrm{M} \mathrm{KOH}+0.20 \mathrm{M}$ zinc acetate solution. The cycling test was performed at $25{ }^{\circ} \mathrm{C}$ 
using the double-pulse method, in which one cycle $(5.0 \mathrm{~mA}$ $\mathrm{cm}^{-2}$ for $20 \mathrm{~min}$ ) consisted of an initial discharging step (5.0 $\mathrm{mA} \mathrm{cm}-2$ for $10 \mathrm{~min}$ ) and a consequent charging step with the same current density and duration time.

\section{Results and discussion}

All the materials show nitrogen adsorption and desorption isotherms (Fig. 1(b)) that are similar in shape. The curves are typical type-IV isotherms associated with an H3 hysteresis loop, which implies a mesoporous structure [28]. As shown in Table S1, it was found that all the samples possess a high specific surface area $\left(S_{\mathrm{BET}}\right)$, which is consistent with previous reports [29]. Moreover, all the samples show a narrow pore size distribution in the range of 2-7 nm (Fig. S1). High specific surface area and mesoporous structure are believed to favor electrocatalysis, as discussed below.

Fig. 1(c) presents the X-ray diffraction (XRD) patterns of the catalysts. All of the catalysts show a broad and strong peak located at approximately $26.4^{\circ}$, which is assigned to the (002) plane of graphitic carbon. It was further found that the crystalline phase of the metal oxide evolves with the composition. First, Fe/NOMC presents the characteristic crystal phase of $\mathrm{Fe}_{3} \mathrm{O}_{4}$ (PDF\#75-0033). Second, the incorporation of Co has a remarkable effect on the diffraction pattern, and the diffraction peaks show a positive shift for FeCo/NOMC and $\mathrm{Fe}_{0.5} \mathrm{Co} / \mathrm{NOMC}$. Such an evolution is understandable because the incorporated cobalt randomly occupies the tetrahedral/octahedral sites in spinel $\mathrm{Fe}_{3} \mathrm{O}_{4}$, generating a new spinel phase, $\mathrm{Co}_{x} \mathrm{Fe}_{3-x} \mathrm{O}_{4}$ [30-32]. When the Co content is further increased, it can be seen that $\mathrm{Fe}_{0.5} \mathrm{Co} / \mathrm{NOMC}$ includes two spinel phases, viz. $\mathrm{Co}_{x} \mathrm{Fe}_{3-x} \mathrm{O}_{4}$ and $\mathrm{Co}_{3} \mathrm{O}_{4}$ (PDF\#42-1467) [33,34]. Finally, $\mathrm{Co} / \mathrm{NOMC}$ shows the characteristic spinel phase of $\mathrm{Co}_{3} \mathrm{O}_{4}$ (PDF\#42-1467).
A ${ }^{57} \mathrm{Fe}$ Mössbauer spectrum was recorded to study the spinel structure (Fig. 1(d), Table S2). $\mathrm{Fe}_{0.5} \mathrm{Co} / \mathrm{NOMC}$ shows a typical sextet curve, which can be well fitted with one quadrupole doublet and two sextets. The quadrupole doublet component, where $\delta=0.43 \mathrm{~mm} \mathrm{~s}^{-1}$ and $\Delta E_{\mathrm{Q}}=0.79 \mathrm{~mm} \mathrm{~s}^{-1}$, is assigned to a superparamagnetic iron species $[35,36]$. The two sextets arise from spinel iron oxide species in tetrahedral (A) and octahedral (B) sites [37]. Peaks belonging to either iron nitride or carbide species were not detected [38], indicating that iron exists solely in the spinel oxide phase. The contents of Fe and Co were further measured by inductively coupled plasma optic emission spectrometry (ICP-OES); the results are summarized in Table S3. These results match well with the feed ratios. Based on the above discussion, it was inferred that the metal oxide of $\mathrm{Fe}_{x-}$ Co/NOMC is in the spinel phase of $\mathrm{CoFe}_{2} \mathrm{O}_{4}, \mathrm{Co}_{1.5} \mathrm{Fe}_{1.5} \mathrm{O}_{4}$, and $\mathrm{Co}_{x} \mathrm{Fe}_{3-x} \mathrm{O}_{4} /(2-x) \mathrm{Co}_{3} \mathrm{O}_{4}(1.5<x<2)$.

Scanning electron microscopy (SEM) images (Fig. S2) show that all the materials exhibit rod-like structures. Transmission electron microscopy (TEM) images (Figs. 2(a) and S3) reveal their ordered mesoporous structures, on which the metal oxide nanoparticles are uniformly dispersed. The average diameters of the metal oxide particles are 3.5, 7.5, 13.7, 15.1 and $17.5 \mathrm{~nm}$ for Fe/NOMC, $\mathrm{Fe}_{2} \mathrm{Co} / \mathrm{NOMC}$, FeCo/NOMC, $\mathrm{Fe}_{0.5} \mathrm{Co} / \mathrm{NOMC}$, and Co/NOMC, respectively. Therefore, the incorporation of cobalt dramatically increases the particle size of the metal oxide, as discovered previously $[39,40]$. The energy dispersive spectroscopy (EDS) results are shown in Fig. S4, indicating that the weight ratios of Fe:Co are 2.01, 1.15, and 0.45 for $\mathrm{Fe}_{2} \mathrm{Co} / \mathrm{NOMC}$, $\mathrm{FeCo} / \mathrm{NOMC}$, and $\mathrm{Fe}_{0.5} \mathrm{Co} / \mathrm{NOMC}$, respectively. In addition, the elemental mapping images (Figs. 2(d)-(f)) show that both Fe and Co are uniformly distributed on the carbon.

The surface composition and chemical state were investigated using X-ray photoelectron spectroscopy (XPS). The survey and high-resolution spectra are shown in Figs. 3-5, S6 and
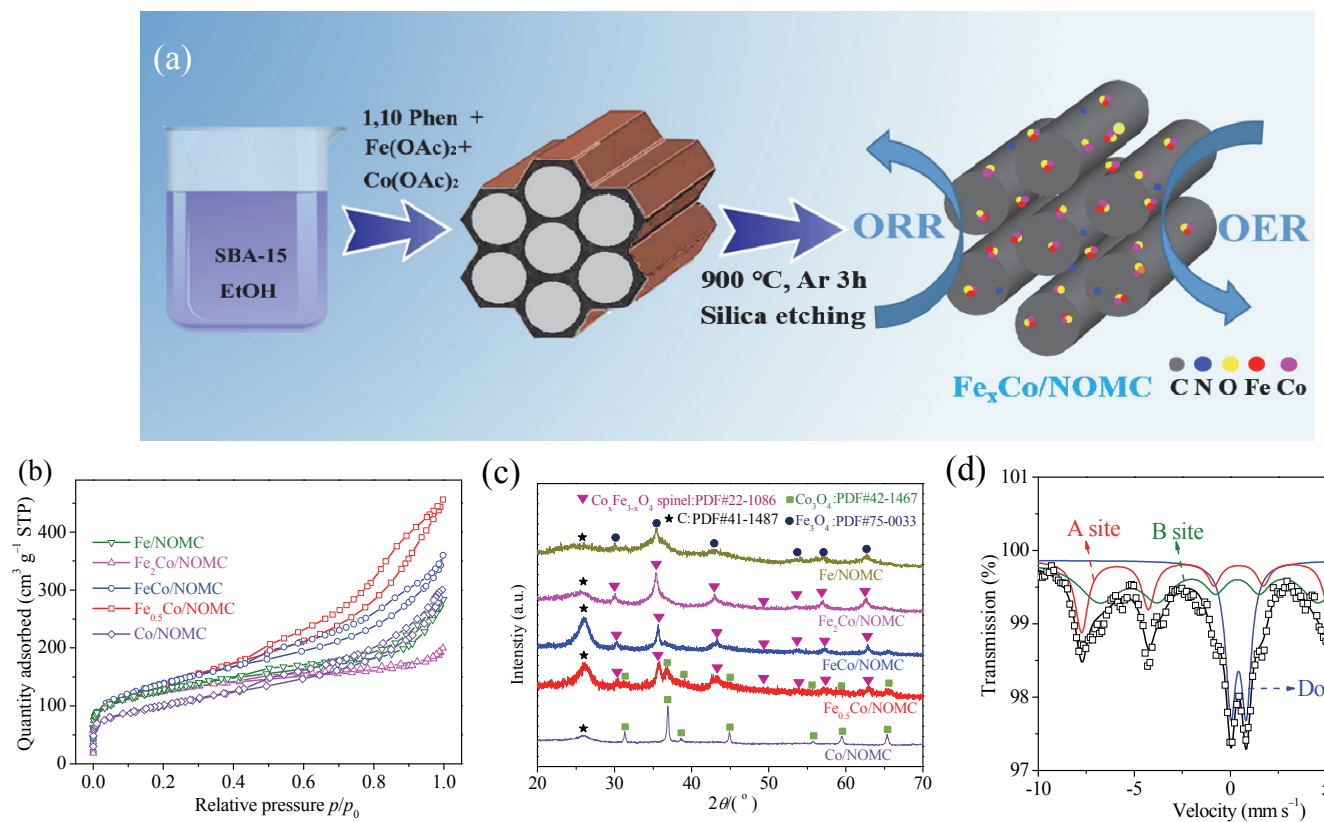

(c)

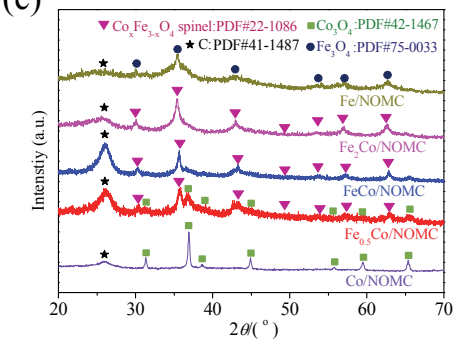

(d)

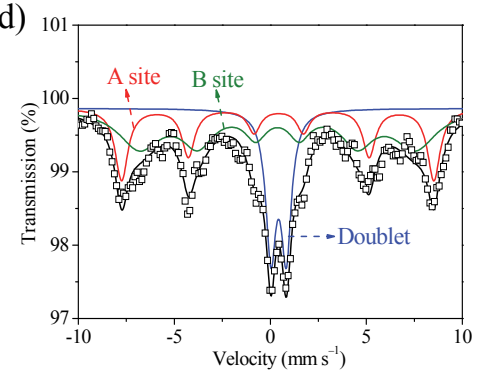

Fig. 1. (a) Schematic illustration of the synthesis protocol of Fe $\mathrm{x}_{\mathrm{C}}$ /NOMC; (b) Nitrogen ad/de-sorption isotherms and (c) XRD patterns of all the samples; (d) Mössbauer spectroscopy of $\mathrm{Fe}_{0.5} \mathrm{Co} / \mathrm{NOMC}$. 

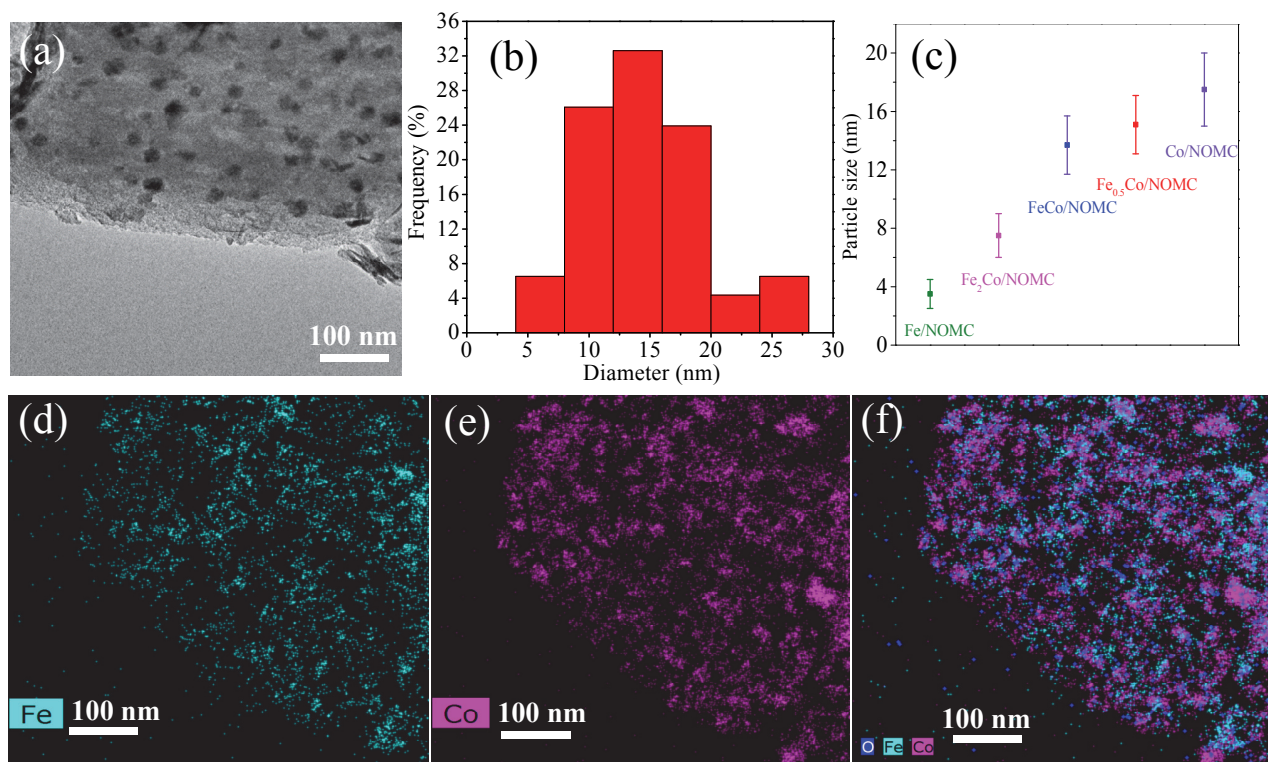

Fig. 2. (a) TEM image and b) corresponding particle size distribution diagram of Fe..5 Co/NOMC; (c) Size distribution of all the samples; (d-f) Elemental mapping images of $\mathrm{Fe}_{0.5} \mathrm{Co} / \mathrm{NOMC}$.

S7. The elemental compositions were quantified and are listed in Table 1. The molar ratios of Fe:Co were 1.82, 0.78, and 0.53 for $\mathrm{Fe}_{2} \mathrm{Co} / \mathrm{NOMC}$, FeCo/NOMC, and $\mathrm{Fe}_{0.5} \mathrm{Co} / \mathrm{NOMC}$, respectively. The molar ratio on the surface, measured by XPS, deviates from that of the bulk measured by ICP-OES and EDS. For the former two samples, the surface shows a slightly smaller ratio than the bulk; in comparison, for $\mathrm{Fe}_{0.5} \mathrm{Co} / \mathrm{NOMC}$, the molar ratio of the surface is much larger than that of the bulk. This may be due to the evolution of the crystalline structure, as shown by XRD. The surface composition likely has a significant effect on electrocatalytic activity, as discussed later.

The curve fitting result of the high-resolution $\mathrm{C} 1 \mathrm{~s}$ peak is shown in Fig. S6. The fraction of nitrogen-activated carbon, which acts as the ORR active site [27,41], increases from $12.27 \%$ to $14.93 \%$ with increasing Co content (Table S4) for $\mathrm{Fe}_{x} \mathrm{Co} / \mathrm{NOMC}$.

The Fe $2 p$ XPS spectra (Fig. 4) show peaks at 710.9, 714.7, 724.3 and $728.6 \mathrm{eV}$, which correspond to $\mathrm{Fe}^{2+} 2 p_{3 / 2}, \mathrm{Fe}^{3+} 2 p_{3 / 2}$, $\mathrm{Fe}^{2+} 2 p_{1 / 2}$, and $\mathrm{Fe}^{3+} 2 p_{1 / 2}$, respectively [42]. Similarly, the peaks in Fig. 5 at 780.9 and $796.2 \mathrm{eV}$ can be assigned to $\mathrm{Co}^{3+} 2 p_{3 / 2}$ and $\mathrm{Co}^{3+} 2 p_{1 / 2}$, respectively. These results confirm the coexistence of two valence states in $\mathrm{Fe}_{0.5} \mathrm{Co} / \mathrm{NOMC}$ [43]. The contents of each iron and cobalt component are summarized in Table S6. It can be seen that the molar ratio of $\mathrm{Fe}^{3+}: \mathrm{Fe}^{2+}$ remarkably increases with the increase in Co content; in comparison, the

Table 1

Elemental composition (at. \%) measured by XPS.

\begin{tabular}{lcccccc}
\hline Sample & $\mathrm{C}$ & $\mathrm{N}$ & $\mathrm{O}$ & $\mathrm{Fe}$ & $\mathrm{Co}$ & $\mathrm{Fe}: \mathrm{Co}$ \\
\hline $\mathrm{Fe} / \mathrm{NOMC}$ & 81.14 & 1.75 & 15.25 & 1.86 & 0 & - \\
$\mathrm{Fe}_{2} \mathrm{Co} / \mathrm{NOMC}$ & 82.42 & 1.76 & 13.16 & 1.72 & 0.94 & 1.83 \\
$\mathrm{FeCo} / \mathrm{NOMC}$ & 83.36 & 1.79 & 12.52 & 1.08 & 1.25 & 0.78 \\
$\mathrm{Fe}_{0.5} \mathrm{Co} / \mathrm{NOMC}$ & 82.41 & 1.82 & 13.39 & 0.82 & 1.56 & 0.53 \\
$\mathrm{Co} / \mathrm{NOMC}$ & 81.01 & 1.50 & 15.76 & 0 & 1.73 & - \\
\hline
\end{tabular}

molar ratio of $\mathrm{Co}^{3+}: \mathrm{Co}^{2+}$ decreases in a mild trend. This result indicates that there is a strong electronic interaction between the two transition metals, which results in a significant effect on the electrocatalysis.

The ORR activity was evaluated by recording linear sweep voltammograms (LSVs) using the rotating disk electrode (RDE) method, as shown in Fig. 6(a). It can be seen that $\mathrm{Fe}_{0.5} \mathrm{Co} / \mathrm{NOMC}$ exhibits the highest ORR performance among the five samples. The half-wave potential $\left(E_{1 / 2}\right)$ of $\mathrm{Fe}_{0.5} \mathrm{Co} / \mathrm{NOMC}$ reaches $0.89 \mathrm{~V}$ $v s$. RHE, implying that it outperforms the non-precious metal catalysts reported in the literature (Table S7). The remarkable activity originates from both the composition and structure of the catalyst. First, it has been claimed that the ORR activity is positively correlated with the content of nitrogen-activated carbon (C-N). As mentioned in the XPS analysis, $\mathrm{Fe}_{0.5} \mathrm{Co} / \mathrm{NOMC}$

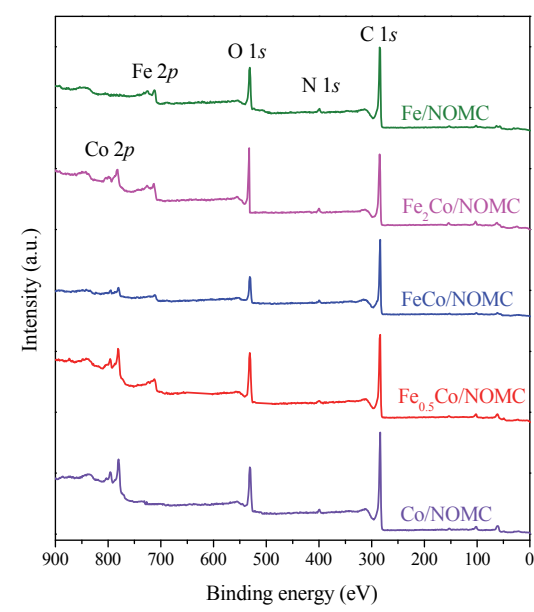

Fig. 3. XPS survey spectra of $\mathrm{Fe} / \mathrm{NOMC}, \mathrm{Fe}_{2} \mathrm{Co} / \mathrm{NOMC}, \mathrm{FeCo} / \mathrm{NOMC}$, $\mathrm{Fe}_{0.5} \mathrm{Co} / \mathrm{NOMC}$ and $\mathrm{Co} / \mathrm{NOMC}$. 

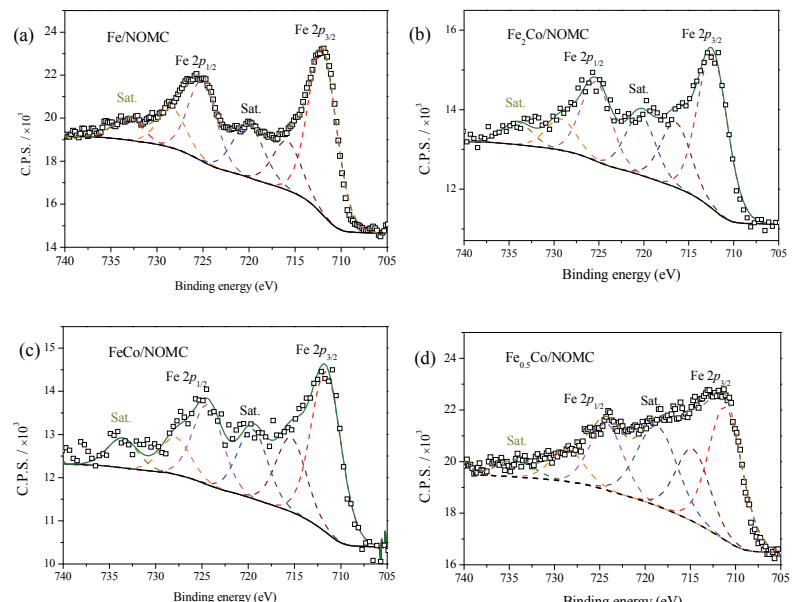

Fig. 4. High-resolution XPS spectra of $\mathrm{Fe} 2 p$ peak and peak fitting result of (a) Fe/NOMC, (b) $\mathrm{Fe}_{2} \mathrm{Co} / \mathrm{NOMC}$, (c) FeCo/NOMC, (d) $\mathrm{Fe}_{0.5} \mathrm{Co} / \mathrm{NOMC}$.

has the highest $\mathrm{C}-\mathrm{N}$ fraction and thus exhibits the best electrocatalytic activity. Second, the ordered mesoporous structure is known to favor both the mass transfer of active species and exposure of the active sites. Finally, the electron transfer number $(n)$, which was measured by the rotating ring-disk electrode (RRDE) method, reveals that the ORR occurs via a 4-electron pathway on the investigated catalysts (Fig. 6(c)).

Fig. 6(d) shows the LSVs of the OER without $i R$ correction. It can be seen that the activity follows the order of $\mathrm{Fe}_{0.5} \mathrm{Co} / \mathrm{NOMC}$ $>\mathrm{FeCo} / \mathrm{NOMC}>\mathrm{Fe}_{2} \mathrm{Co} / \mathrm{NOMC}>\mathrm{IrO}_{2}>\mathrm{Co} / \mathrm{NOMC}>\mathrm{Fe} / \mathrm{NOMC}$. For clearer viewing, the overpotential at $10 \mathrm{~mA} \mathrm{~cm}-2$ was ex-

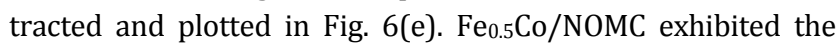
lowest overpotentials of $0.31 \mathrm{~V}$ at $10 \mathrm{~mA} \mathrm{~cm}^{-2}$ and $0.42 \mathrm{~V}$ at $100 \mathrm{~mA} \mathrm{~cm}^{-2}$. The good activity can be attributed to both the
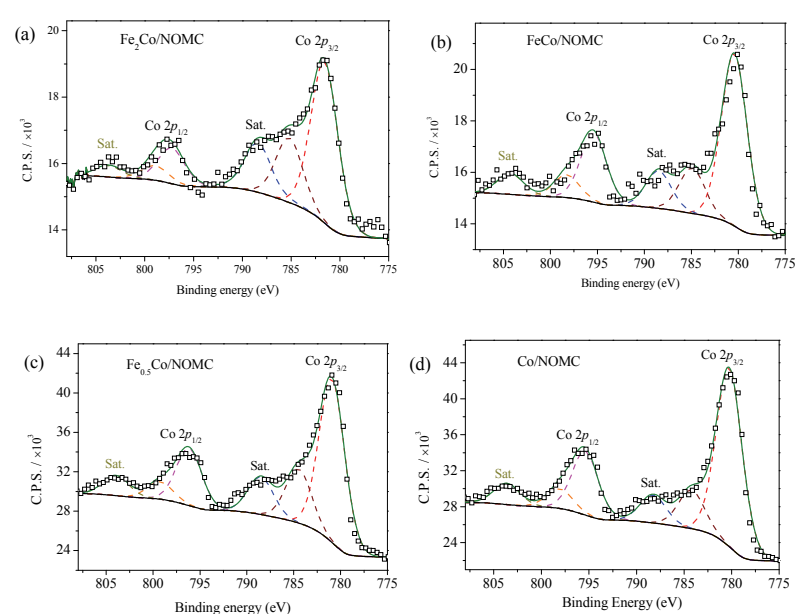

Fig. 5. High-resolution XPS spectra of Co $2 p$ peak and peak fitting result of (a) $\mathrm{Fe}_{2} \mathrm{Co} / \mathrm{NOMC}$, (b) FeCo/NOMC, (c) $\mathrm{Fe}_{0.5} \mathrm{Co} / \mathrm{NOMC}$, (d) Co/NOMC.

surface composition and the synergistic effect between Co and $\mathrm{Fe}$ in $\mathrm{Fe} 0.5 \mathrm{Co} / \mathrm{NOMC}$. In addition, the ordered mesoporous structure exposes the active sites and extends the catalyst-electrolyte interface, which benefits the electrocatalysis and mass transfer for the OER [44-46]. Finally, it is worth noting that for the OER, the activity of $\mathrm{Fe}_{0.5} \mathrm{Co} / \mathrm{NOMC}$ is on par with most catalysts reported in the literature (Table S8).

The potential gap $\left(\Delta E=E_{\text {OER@10 }}-E_{1 / 2}\right)$ between the OER potential at $10 \mathrm{~mA} \mathrm{~cm}^{-2}$ and the ORR half-wave potential was used to evaluate the electrochemical reversibility of the oxygen-related electrode, where lower $\Delta E$ implies higher reversibility and better ORR/OER activity [47]. As shown in Figs. 6(f) and $\mathrm{S} 8, \mathrm{Fe}_{0.5} \mathrm{Co} / \mathrm{NOMC}$ exhibits the lowest $\Delta E$ of $0.66 \mathrm{~V}$, demonstrating its superior ORR/OER activity.
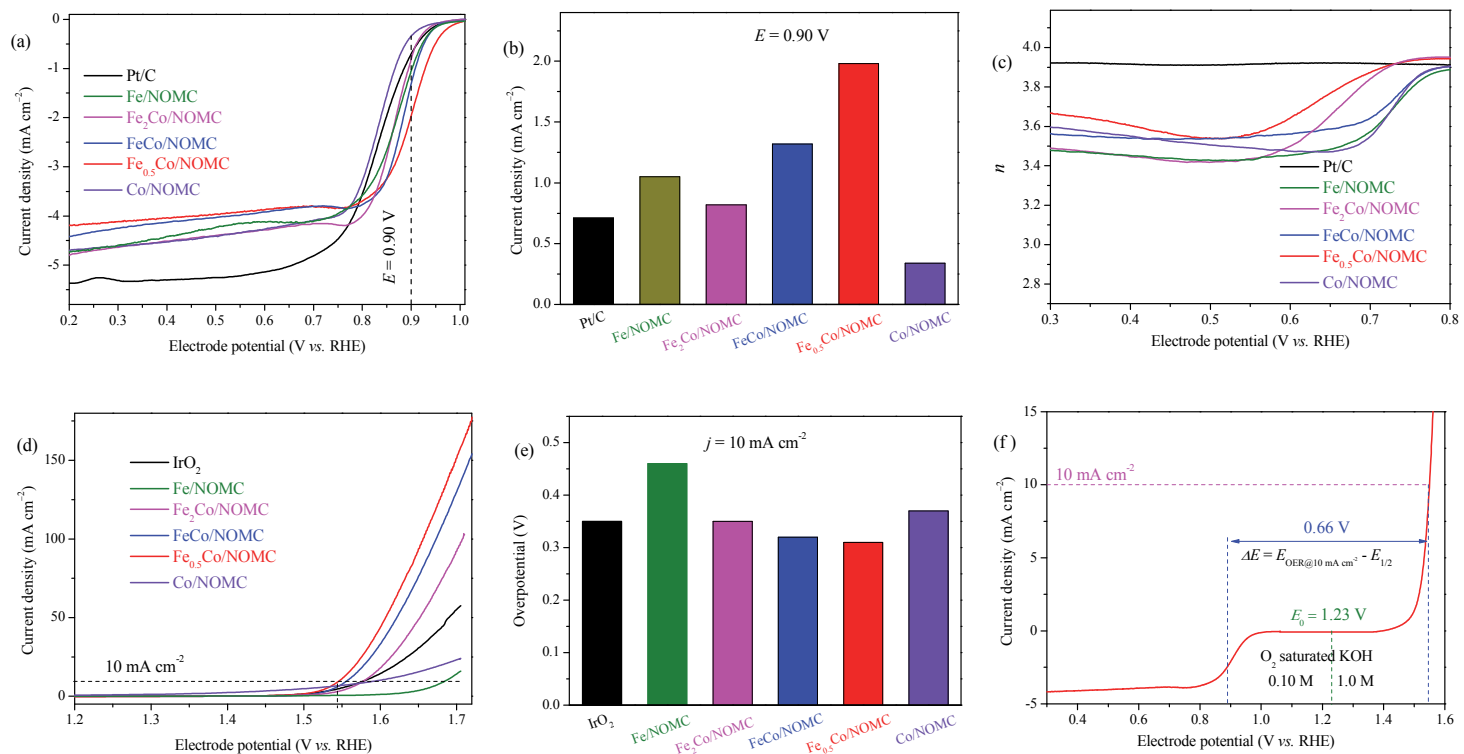

Fig. 6. (a) ORR's polarization curves (scanning rate: $10 \mathrm{mV} \mathrm{s}{ }^{-1}$, rotating rate: $1600 \mathrm{rpm}, \mathrm{O}_{2}$-saturated $0.10 \mathrm{M} \mathrm{KOH}$ solution), (b) the corresponding current density at $0.90 \mathrm{~V}$, and (c) electron transfer number ( $n$ ) of all the catalysts; (d) OER's polarization curves (scanning rate: $5 \mathrm{mV} \mathrm{s}^{-1}$, rotating rate: $1600 \mathrm{rpm}, \mathrm{O}_{2}$-saturated $1.0 \mathrm{M} \mathrm{KOH}$ solution), and (e) OER's overpotential at $10 \mathrm{~mA} \mathrm{~cm}-2$ of all the catalysts; (f) Full-potential-window polarization curve of $\mathrm{Fe}_{0.5} \mathrm{Co} / \mathrm{NOMC}$. 

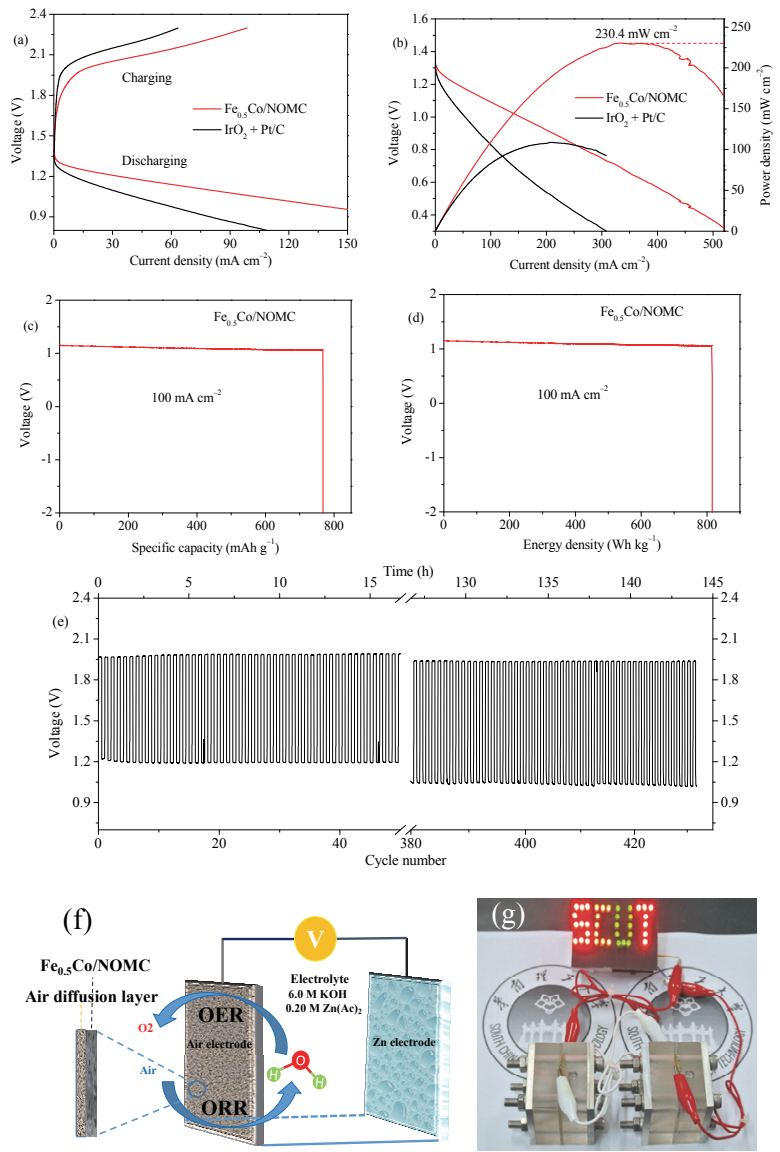

Fig. 7. (a) Discharging and charging polarization curves, and (b) power density diagram of $\mathrm{Zn}$-air battery assembled with $\mathrm{Fe}_{0.5} \mathrm{Co} / \mathrm{NOMC}$ and $\mathrm{IrO}_{2}+\mathrm{Pt} / \mathrm{C}$, respectively; (c) Specific capacity and (d) specific energy density diagrams at $100 \mathrm{~mA} \mathrm{~cm}-2$, and (e) cycling performance at $5 \mathrm{~mA}$ $\mathrm{cm}^{-2}$ for 10 min discharging and 10 min charging of Zn-air battery assembled with $\mathrm{Fe}_{0.5} \mathrm{Co} / \mathrm{NOMC}$; (f) Schematic of the rechargeable Zn-air battery; (g) Photo of thirty-eight LEDs powered by two rechargeable Zn-air batteries Photo of 38 LEDs powered by two rechargeable Zn-air batteries.

The best-performing catalyst, viz. $\mathrm{Fe}_{0.5} \mathrm{Co} / \mathrm{NOMC}$, was used to fabricate the air electrode and assemble a zinc-air battery. Typical discharging/charging polarization curves are shown in Fig. 7(a). The voltage at $50 \mathrm{~mA} \mathrm{~cm}^{-2}$ of $\mathrm{Fe}_{0.5} \mathrm{Co} / \mathrm{NOMC}$ was 1.09 $\mathrm{V}$, which is significantly lower than that of $\mathrm{IrO}_{2}+\mathrm{Pt} / \mathrm{C}(1.27 \mathrm{~V})$. The discharging polarization curve and the corresponding power density curve are plotted in Fig. 7(b). The $\mathrm{Fe}_{0.5} \mathrm{Co} / \mathrm{NOMC}$ catalyst yielded a power density of $153.2 \mathrm{~mW} \mathrm{~cm}^{-2}$ at $1.0 \mathrm{~V}$, which is three times higher than that of the noble metal catalyst $\left(\mathrm{IrO}_{2}+\mathrm{Pt} / \mathrm{C}\right)$. The peak power density was found to be 230.4 $\mathrm{mW} \mathrm{cm}-2$, which is among the highest of those reported in the literature (Table S9). Figs. 7(c) and (d) shows the specific capacity and energy density at a constant discharging current density of $100 \mathrm{~mA} \mathrm{~cm}^{-2}$, which reached $770 \mathrm{mAh} \mathrm{g}^{-1}$ and 820 $\mathrm{Wh} \mathrm{kg}^{-1}$, respectively. The cycling stability of the battery is shown in Fig. 7(e). The initial charging/discharging voltage was $1.97 / 1.20 \mathrm{~V}$ at $5 \mathrm{~mA} \mathrm{~cm}^{-2}$ with a voltage gap of $0.77 \mathrm{~V}$. Notably, the battery was stable during 432 cycles $(144 \mathrm{~h})$ of continuous testing with no serious degradation identified. In comparison, the battery using commercial $\mathrm{IrO}_{2}+\mathrm{Pt} / \mathrm{C}$ produced a significantly larger voltage gap and unstable cycling curves under the same test conditions (Fig. S11). To demonstrate its practical usage, a prototype zinc-air battery was assembled with $\mathrm{Fe}_{0.5} \mathrm{Co} / \mathrm{NOMC}$, as shown in Figs. 7(f)-(g). Two rechargeable batteries connected in series were effective to continuously power 38 parallel LEDs in an array displaying SCUT (South China University of Technology).

\section{Conclusions}

In this work, we prepared a spinel Fe-Co oxide/nitrogen-doped ordered mesoporous carbon $\left(\mathrm{Fe}_{x-}\right.$ Co/NOMC) composite catalyst using a one-step method. The feed ratio of Fe:Co has a significant effect on both the surface composition and electronic structure of the catalyst; therefore, the oxygen-related electrocatalysis can be tuned effectively in this way. The optimal catalyst, viz. Fe0.5Co/NOMC, exhibits electrocatalytic activity superior to its commercial counterpart $\left(\mathrm{IrO}_{2}+\mathrm{Pt} / \mathrm{C}\right)$ and is one of the most effective catalysts found in the literature. For demonstration, a catalyst-assembled rechargeable Zn-air battery exhibits superior power density and long-term stability, which can be used as an efficient oxygen-related catalyst in practice.

\section{Electronic supporting information}

Supporting information is available in the online version of this article.

\section{References}

[1] A. Grimaud, O. Diaz-Morales, B. Han, W. T. Hong, Y. L. Lee, L. Giordano, K. A. Stoerzinger, M. T. M. Koper, Y. Shao-Horn, Nat. Chem., 2017, 9, 457-465.

[2] X. G. Guo, G. Z. Fang, G. Li, H. Ma, H. J. Fan, L. Yu, C. Ma, X. Wu, D. H. Deng, M. M. Wei, D. L. Tan, R. Si, S. Zhang, J. Q. Li, L. T. Sun, Z. C. Tang, X. L. Pan, X. H. Bao, Science, 2014, 344, 616-619.

[3] F. Shi, X. Zhu, W. Yang, Chin. J. Catal., 2020, 41, 390-403.

[4] Q. Liu, Y. B. Wang, L. M. Dai, J. N. Yao, Adv. Mater., 2016, 28, 3000-3006.

[5] Y. Guo, Y. N. Chen, H. Cui, Z. Zhou, Chin. J. Catal., 2019, 40, 1298-1310.

[6] Z. M. Cui, Y. T. Li, G. T. Fu, X. Li, J. B. Goodenough, Adv. Mater., 2017, 29, 1702385.

[7] Y. R. Lv, X. J. Zhai, S. Wang, H. Xu, R. Wang, S. Q. Zang, Chin. J. Catal., 2021, 42, 490-500.

[8] C. Tang, B. Wang, H. F. Wang, Q. Zhang, Adv. Mater., 2017, 29, 1703185.

[9] S. Li, X. Tang, H. Jia, H. Li, G. Xie, X. Liu, X. Lin, H.-J. Qiu, J. Catal., 2020, 383, 164-171.

[10] Y. Jiang, Y. P. Deng, J. Fu, D. U. Lee, R. L. Liang, Z. P. Cano, Y. S. Liu, Z. Y. Bai, S. Hwang, L. Yang, D. Su, W. G. Chu, Z. W. Chen, Adv. Energy Mater., 2018, 8, 1702900.

[11] M. Li, F. Luo, Q. Zhang, Z. Yang, Z. Xu, J. Catal., 2020, 381, 395-401.

[12] K. Wan, J. S. Luo, C. Zhou, T. Zhang, J. Arbiol, X. H. Lu, B. W. Mao, X. Zhang, J. Fransaer, Adv. Funct. Mater., 2019, 29, 1900315.

[13] J. Jin, J. Yin, H. Liu, P. Xi, Chin. J. Catal., 2019, 40, 43-51. 


\section{Graphical Abstract}

Chin. J. Catal., 2021, 42: 1451-1458 doi: 10.1016/S1872-2067(20)63752-4

Efficient spinel iron-cobalt oxide/nitrogen-doped ordered mesoporous carbon catalyst for rechargeable zinc-air batteries

He-lei Wei, Ai-dong Tan*, Shu-zhi Hu, Jin-hua Piao, Zhi-yong Fu *

South China University of Technology
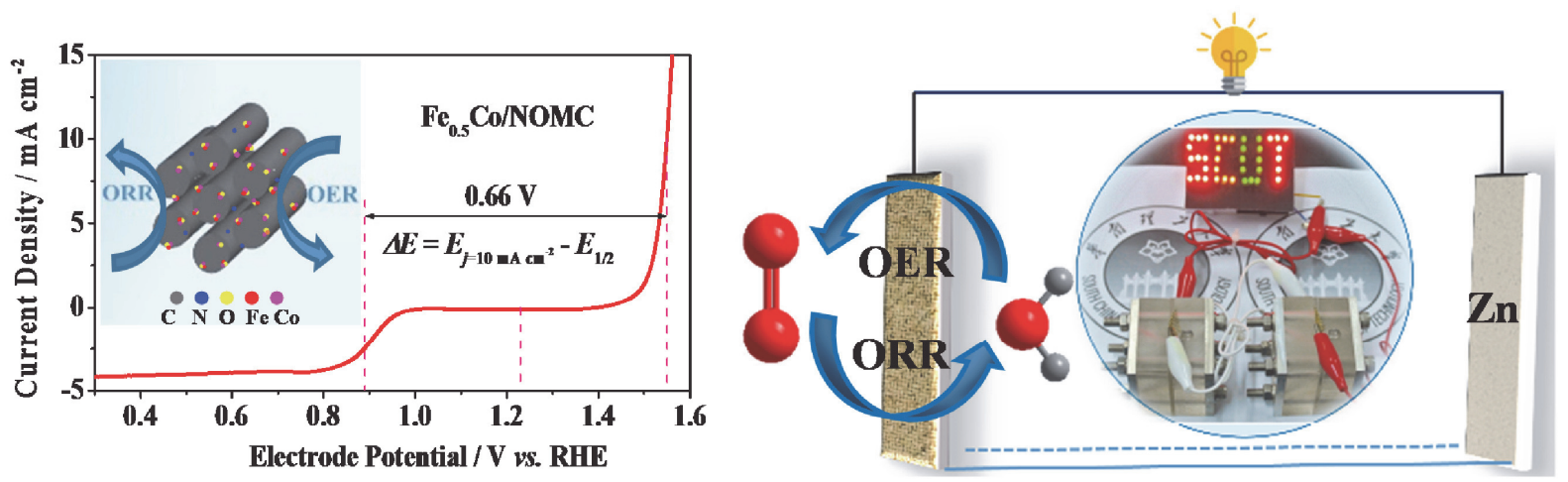

A robust ORR/OER oxygen-related catalyst was synthesized via a one-step method. A rechargeable zinc-air battery assembled using the optimal catalyst, viz. $\mathrm{Fe}_{0.5} \mathrm{Co} / \mathrm{NOMC}$, exhibits a power density of $153 \mathrm{~mW} \mathrm{~cm}-2$ at $1.0 \mathrm{~V}$ and superior cycling stability.

[14] C. Wang, D. Wang, S. Liu, P. Jiang, Z. Lin, P. Xu, K. Yang, J. Lu, H. Tong, L. Hu, W. Zhang, Q. Chen, J. Catal., 2020, 389, 150-156.

[15] C. Y. Su, H. Cheng, W. Li, Z. Q. Liu, N. Li, Z. Hou, F. Q. Bai, H. X. Zhang, T. Y. Ma, Adv. Energy Mater., 2017, 7, 1602420.

[16] K. Chen, S. Ci, Q. Xu, P. Cai, M. Li, L. Xiang, X. Hu, Z. Wen, Chin. J. Catal., 2020, 41, 858-867.

[17] S. Zhou, J. Qin, X. Zhao, J. Yang, Chin. J. Catal., 2021, 42, 571-582.

[18] X. Y. Cai, L. F. Lai, J. Y. Lin, Z. X. Shen, Mater. Horiz., 2017, 4, 945-976.

[19] Y. L. Liu, F. J. Chen, W. Ye, M. Zeng, N. Han, F. P. Zhao, X. X. Wang, Y. G. Li, Adv. Funct. Mater., 2017, 27, 1606034.

[20] S. J. Liu, I. S. Amiinu, X. B. Liu, J. Zhang, M. J. Bao, T. Meng, S. C. Mu, Chem. Eng. J., 2018, 342, 163-170.

[21] W. Yuan, Y. Wang, P. Chernev, K. Klingan, M. Reza Mohammadi, S. Loos, C. Pasquini, P. Kubella, S. Jiang, Z. Cui, S. Zhu, Z. Li, S. Wu, H. Dau, J. Zhang, Y. Liang, J. Catal., 2020, 383, 221-229.

[22] X. Liu, M. Park, J. Cho, G. M. Kim, S. Gupta, G. Wu, Angew. Chem. Int. Ed., 2015, 54, 9654-9658.

[23] C. Guan, A. Sumboja, H. J. Wu, W. N. Ren, X. M. Liu, H. Zhang, Z. L. Liu, C. W. Cheng, S. J. Pennycook, J. Wang, Adv. Mater., 2017, 25, 1704117

[24] Y. B. Li, C. Zhong, J. Liu, X. Q. Zeng, S. X. Qu, X. P. Han, Y. D. Deng, W. B. Hu, J. Lu, Adv. Mater., 2018, 30, 1703657.

[25] X. H. Li, K. Wan, Q. B. Liu, J. H. Piao, Y. Y. Zheng, Z. X. Liang, Chin. J. Catal., 2016, 37, 1562-1567.

[26] K. Wan, M. Y. Liu, Z. P. Yu, Z. X. Liang, Q. B. Liu, J. H. Piao, Y. Y. Zheng, Int. J. Hydrogen Energy, 2016, 41, 18027-18032.

[27] K. Wan, A. D. Tan, Z. P. Yu, Z. X. Liang, J. H. Piao, P. Tsiakaras, Appl. Catal. B, 2017, 209, 447-454.

[28] D. P. He, Y. L. Jiang, H. F. Lv, M. Pan, S. C. Mu, Appl. Catal. B, 2013, 132-133, 379-388.

[29] Z. J. Zhang, X. R. Wei, Y. Yao, Z. Chen, A. J. Zhang, W. Li, W. D. Wu, Z. X. Wu, X. D. Chen, D. Y. Zhao, Small, 2017, 13, 1702243.
[30] P. A. Smith, C. D. Spencer, R. P. Stillwell, J. Phys. Chem. Solids, 1978, 39, 107-111.

[31] R. N. Bhowmik, V. Vasanthi, A. Poddar, J. Alloys Compd., 2013, 578, 585-594.

[32] Y. Feng, J. Wei, Y. Ding, J. Phys. Chem. C, 2015, 120, 517-526.

[33] T. Dippong, E. A. Levei, L. Diamandescu, I. Bibicu, C. Leostean, G. Borodi, L. Barbu Tudoran, J. Magn. Magn. Mater., 2015, 394, 111-116.

[34] I. C. Nlebedim, A. J. Moses, D. C. Jiles, J. Magn. Magn. Mater., 2013, $343,49-54$.

[35] K. Zhu, C. Jin, Z. Klencsár, J. Wang, Catal. Lett., 2017, 147, 1732-1743.

[36] G. Shen, R. Zhang, L. Pan, F. Hou, Y. Zhao, Z. Shen, W. Mi, C. Shi, Q. Wang, X. Zhang, J. J. Zou, Angew. Chem. Int. Ed., 2020, 59, 2313-2317.

[37] H. Le Trong, L. Presmanes, E. De Grave, A. Barnabé, C. Bonningue, P. Tailhades, J. Magn. Magn. Mater., 2013, 334, 66-73.

[38] X. Xu, Z. Xia, X. Zhang, R. Sun, X. Sun, H. Li, C. Wu, J. Wang, S. Wang, G. Sun, Appl. Catal. B, 2019, 259, 118042.

[39] X. Li, C. Kutal, J. Alloys Compd., 2003, 349, 264-268.

[40] K. S. Park, M. H. Jeong, J. W. Bae, Catalysts, 2020, 10, 461.

[41] K. Wan, G. F. Long, M. Y. Liu, L. Du, Z. X. Liang, P. Tsiakaras, Appl. Catal. B, 2015, 165, 566-571.

[42] W. H. Niu, L. G. Li, X. J. Liu, N. Wang, J. Liu, W. J. Zhou, Z. H. Tang, S. W. Chen, J. Am. Chem. Soc., 2015, 137, 5555-5562.

[43] W. Ahn, M. G. Park, D. U. Lee, M. H. Seo, G. P. Jiang, Z. P. Cano, F. M. Hassan, Z. W. Chen, Adv. Funct. Mater., 2018, 28, 1802129.

[44] D. U. Lee, J. Y. Choi, K. Feng, H. W. Park, Z. W. Chen, Adv. Energy Mater., 2014, 4, 1301389.

[45] Q. Wang, L. Shang, R. Shi, X. Zhang, G. I. N. Waterhouse, L. Z. Wu, C. H. Tung, T. R. Zhang, Nano Energy, 2017, 40, 382-389.

[46] M. G. Park, D. U. Lee, M. H. Seo, Z. P. Cano, Z. W. Chen, Small, 2016, $12,2707-2714$. 


\title{
高效的尖晶石铁钴氧/氮掺杂有序介孔碳催化剂应用于可充电锌-空气电池
}

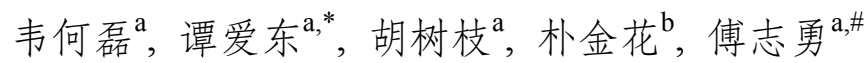 \\ a华南理工大学化学与化工学院, 广东省燃料电池技术重点实验室, 广东广州510641 \\ b华南理工大学食品科学与工程学院, 广东广州510641
}

\begin{abstract}
摘要: 以电催化为核心的新能源储存和转换技术为缓解能源与环境问题提供了有效手段. 可充电锌空气电池因其理论能 量密度 $\left(1086 \mathrm{Wh} \cdot \mathrm{kg}^{-1}\right)$ 高、成本效益显著、安全系数高、环境友好及放电平稳等优点被认为是一种具有前景的能源存储/ 转换装置, 有望在新能源汽车、便携式电源等领域广泛应用. 氧还原反应(ORR)和氧析出反应(OER)是锌-空气电池中的核 心反应, 目前, 虽然贵金属催化剂对上述反应表现出一定的电催化活性, 但由于其稀缺性、高昂价格和低稳定性因素严重阻 碍了它们在锌-空气电池中的广泛应用. 而非贵金属催化剂所面临的瓶颈在于ORR/OER反应动力学缓慢, 导致其在实际应 用过程中存在电压效率低和催化剂腐蚀等问题. 因此, 为了推进锌-空气电池商业化进程, 研制低成本、高效、稳定的非贵 金属催化剂迫在眉睫.

本文通过一步法将双金属前驱体嵌入氮掺杂有序介孔碳(NOMC)中, 合成了具有尖晶石型铁钴氧化物的高性能非贵金 属电催化剂 $\left(\mathrm{Fe}_{x} \mathrm{Co} / \mathrm{NOMC}, x\right.$ 代表铁钴的摩尔比). 实验结果表明, 在 $x=0.5$ 时, 所制备的催化剂具有最佳的催化活性, 与商 业贵金属催化剂相比, 该催化剂展现更优的电催化活性和稳定性. 电化学测试结果表明, 其ORR的半波电位为 $0.89 \mathrm{~V}(\mathrm{vs}$. RHE), 当OER电流密度为 $10 \mathrm{~mA} \cdot \mathrm{cm}^{-1}$ 时, 过电势仅为 $0.31 \mathrm{~V}$, 且电流-时间曲线测试结果表明催化剂表现出较好的稳定性. 通过X射线光电子能谱(XPS)、穆斯堡尔谱(Mössbauer)、扫描电子显微镜(SEM)、透射电子显微镜(TEM)和拉曼光谱(Raman) 等表征手段对电催化剂的物化性质进行表征, 结果表明该材料优异的氧电催化性能归因于双金属氧化物的电子调控作用、 $\mathrm{NOMC}$ 的介孔结构、高导电性和高比表面积, 其ORR与 $\mathrm{OER}$ 的催化活性位点分别是氮活化的碳 $(\mathrm{N}-\mathrm{C})$ 和双金属氧化物. 以优 化的 $\mathrm{Fe}_{0.5} \mathrm{Co} / \mathrm{NOMC}$ 为正极组装可充电锌-空气电池, 该电池在空气环境下展现出优良的充放电性能, 其在电流密度为 100 $\mathrm{mA} \cdot \mathrm{cm}^{-2}$ 条件下操作时能量密度达到 $820 \mathrm{Wh} \cdot \mathrm{kg}^{-1}$, 在 $1.0 \mathrm{~V}$ 时功率密度达到 $153 \mathrm{~mW} \cdot \mathrm{cm}^{-2}$, 它还表现出较好的稳定性, 经过 $144 \mathrm{~h}$ 的循环实验, 活性没有明显下降. 本文不仅制备了一种有前景的尖晶石型氧化物碳基氧电催化材料, 还为高效氧电催 化剂的合理开发与构筑提供了一条新的思路.
\end{abstract}

关键词: 氧相关催化剂; 氧析出反应; 氧还原反应; 尖晶石氧化物; 锌空气电池

收稿日期: 2020-11-25. 接受日期: 2020-12-22. 上网时间: 2021-05-05.

*通讯联系人. 电话: (020)87113584; 电子信箱: tanad@scut.edu.cn

通讯联系人. 电子信箱: zyfu@scut.edu.cn

基金来源：国家自然科学基金(21903026, 21975081,21975079); 博士后科学基金(2019M652877); 中央高校基础研究基金.

本文的电子版全文由Elsevier出版社在ScienceDirect上出版(http://www.sciencedirect.com/journal/chinese-journal-of-catalysis). 